\title{
Different roughage to concentrate ratios in extruded ration and metabolic parameters of growing lambs
}

\section{Diferentes relações de volumoso e concentrado na ração extrusada e parâmetros metabólicos de borregas em crescimento}

\author{
Karla Alves Oliveira ${ }^{1 *}$; Gilberto de Lima Macedo Júnior²; \\ Carolina Moreira Araújo ${ }^{3}$; Luciano Fernandes Sousa ${ }^{4}$; \\ Maria Júlia Pereira de Araújo ${ }^{5}$, Marco Túlio Santos Siqueira ${ }^{6}$
}

\begin{abstract}
Highlights:
A higher proportion of concentrate in lambs' feed provides less dry matter intake.

The concentration of blood metabolites was higher when the DMI\% BW was high.

The diets were efficient in maintaining the animals' metabolic conditions.

The maintained metabolic conditions, associated with the dry matter intake, may favour the performance of growing lambs.
\end{abstract}

\begin{abstract}
The objective of this study was to evaluate the dry matter intake and metabolic parameters of 30 lambs fed with extruded ration with different roughage to concentrate ratios. It was carried out at the Federal University of Uberlândia from 7 December 2016 to 22 March 2017. The treatments were extruded rations, at 30\% roughage and $70 \%$ concentrate (30R:70C) and $70 \%$ roughage and $30 \%$ concentrate (70R:30C) ratios, distributed completely randomly with two treatments and 15 animals per treatment. The treatment means were evaluated by the Tukey test and a regression study with a significance level of $5 \%$. The dry matter intake (DMI) was evaluated. Blood was collected via jugular venipuncture to determine the concentration of energy-related, protein and mineral metabolites as well as enzymes indicative of hepatic and muscular activity. There was lower DMI for the 30R:70C treatment, as well as reduction in DMI in relation to body weight at the end of the experiment. The treatments influenced urea: animals with higher urea concentrations consumed the ration with higher concentrate content. Further, animals fed with more roughage had a higher concentration of phosphorus. In conclusion, the roughage to concentrate ratio of the extruded ration influenced the dry matter intake without triggering metabolic disorders in the animals.
\end{abstract}

Key words: Energetic. Extrusion. Ovis aries. Protein.

\footnotetext{
1 Discente do Curso de Doutorado do Programa de Pós Graduação em Zootecnia, Universidade Estadual Paulista "Júlio de Mesquita Filho", UNESP, Jaboticabal, SP, Brasil. E-mail: karla.alves.oliveira@hotmail.com

2 Prof. Dr., Universidade Federal de Uberlândia, UFU, Uberlândia, MG, Brasil. E-mail:gilbertomacedojr@gmail.com

3 Discente do Curso de Doutorado do Programa de Pós-Graduação em Ciências Veterinárias, UFU, Uberlândia, MG, Brasil. E-mail: carolina.am@hotmail.com

4 Prof. Dr., Universidade Federal de Tocantins, UFT, Araguaína, TO, Brasil. E-mail: luciano.sousa@mail.uft.edu.br

5 Zootecnista, UFU, Uberlândia, MG, Brasil. E-mail: mjuliapa@hotmail.com

6 Discente do Curso de Graduação em Zootecnia, UFU, Uberlândia, MG, Brasil. E-mail: marcotulio.s.siqueira@gmail.com

* Author for correspondence
} 


\title{
Resumo
}

\begin{abstract}
Objetivou-se avaliar o consumo de matéria seca e parâmetros metabólicos de 30 borregas alimentadas com ração extrusada em diferentes relações volumoso $(\mathrm{V})$ : concentrado $(\mathrm{C})$. O experimento foi realizado na Universidade Federal de Uberlândia, de 07 de dezembro de 2016 a 22 de março de 2017. Os tratamentos consistiam de ração extrusada nas relações $30 \mathrm{~V}: 70 \mathrm{C}$ e $70 \mathrm{~V}: 30 \mathrm{C}$, distribuídas inteiramente ao acaso com dois tratamentos e 15 repetições. As médias dos tratamentos foram avaliadas pelo teste de Tukey e os períodos de coleta por estudo de regressão ao nível de significância de $5 \%$. Foram avaliados o consumo de matéria seca (CMS), concentração sanguínea dos metabólitos energéticos, proteicos e minerais e concentração sanguínea de enzimas indicadoras de atividade hepática e muscular através de coleta de sangue por venopunção da jugular. Houve menor CMS para o tratamento 30V:70C, e redução do CMS em relação ao peso corporal no final do experimento. Houve influência dos tratamentos para a ureia com maior concentração nos animais consumindo a ração com maior teor de concentrado, enquanto houve maior concentração do fósforo nos animais alimentados com ração com maior teor de volumoso. A relação volumoso: concentrado da ração extrusada exerce influencia sobre o consumo de matéria seca, sem desencadear transtornos metabólicos nos animais.
\end{abstract}

Palavras-chave: Energético. Extrusão. Ovis aries. Proteico.

\section{Introduction}

Animal performance is a direct function of the digestible dry matter intake (DMI), and food intake varies depending on the animal (live weight and its variations, level of production, physiological state and size), the food (fibre, volume, capacity to fill/ satiate, energy density and need for chewing) and feeding conditions (availability of food, space in the trough, access time to food, frequency of feeding, etc.), in addition to climatic conditions (Mertens, 1994; Gesualdi et al., 2000).

The intake of a high-fibre diet is controlled by physical factors, such as the passage rate and rumen filling, whereas the intake of diets with high concentrate levels (high energy density) is controlled by energy demand and metabolic factors (Conrad, Weiss, Odwongo, \& Shockey, 1984; Mertens, 1987; Van Soest, 1994). Therefore, the animal's energy demands define the intake of high caloric diets, whereas the physical capacity of the gastrointestinal tract determines the intake of low-quality and relatively energy poor diets. Thus, it is necessary to define an adequate roughage to concentrate balance in diets. This factor is influenced by age, the quality of roughage and the concentrate and the productivity that is expected to be achieved.
One tool to assess whether the nutrition offered to an animal is adequate and meets their nutritional requirements is evaluation of the animal's metabolic profile. Specifically, the blood concentrations of some metabolites are quantified; increases or decreases in their levels may indicate nutrient excess or deficiency in their diet., \& also, according to Contreras and Phil (2000) this technique can diagnose biochemical changes that decrease production, reduce fertility, are responsible for diseases or lead to the death of these animals.

Energy-related and protein metabolites are widely used to assess the nutritional profile of a ruminant. The most utilised energy metabolites are glucose, beta-hydroxybutyrate, free fatty acids, cholesterol and triglycerides, all of which help evaluate the fermentation of carbohydrates in the rumen, especially with regard to the fibrous part of the diet. The most used protein metabolites are total proteins, albumin and urea; they help determine whether the amount of protein offered in the diet is adequate, since it is the nutrient of greatest economic cost (Pegoraro et al., 2017). It is worth mentioning that in addition to considering the metabolic profile in the nutritional assessment of the animal, aspects of management, health and physiological status must also be taken into account. 
The objective of this work was to evaluate the effect of two roughage to concentrate ratios- $-30 \%$ roughage and $70 \%$ concentrate (30R:70C) and 70\% roughage and $30 \%$ concentrate (70R: $30 \mathrm{C}$ ) - on DMI and the blood concentration of energy-related, protein and mineral metabolites, as well as liver and muscle enzymes, of growing lambs.

\section{Material and Methods}

The experiment was carried out at the Federal University of Uberlândia(UFU), Experimental Farm Capim Branco, located in the city of Uberlândia, Minas Gerais. The experimental period was from 7 December 2016 to 1 April 2017. The experimental protocol for this work was approved by the UFU Ethics Committee on the Use of Animals (CEUA) under number 140/16.

Thirty 3-month-old crossbred lambs (Santa Inês x Dorper) were used, with an average weight of $20.7 \pm 4.7 \mathrm{~kg}$. All animals were weighed and dewormed with levamisole (orally) on the first day of the experiment. Before the beginning of the experiment, the animals had consumed a diet based on corn silage and bran concentrate (corn bran, soybean meal, urea and mineral salt).

The experiment lasted 105 days: the first 15 days were used to adapt the animals to the stalls and the diet, and the remaining 90 days involved data collection. The animals were divided into six collective stalls (each stall had five animals), with three stalls for each evaluated treatment. These stalls were approximately $20 \mathrm{~m}^{2}$ in size and were located in a masonry shed under a covered area (clay tile). Each stall was equipped with an external feeder, drinking fountain, salt shaker and suspended slatted floor. The animals had access to water and mineral salt ad libitum.

The feed during the experiment was exclusively extruded. Roughage and concentrate were present in the same pellet; the fibrous component comprised forages of the genus Urochloa, while the concentrated part comprised corn bran, soybean meal, starch, minerals and monensin. Therefore, the treatments were divided according to the roughage to concentrate ratio of the diet: $70 \mathrm{R}: 30 \mathrm{C}$ and 30R:70C. The chemical composition of the treatments is shown in Table 1.

\section{Table 1}

\section{Chemical composition of treatments}

\begin{tabular}{ccc}
\hline Nutrient & $70 \mathrm{R}: 30 \mathrm{C}$ & $30 \mathrm{R}: 70 \mathrm{C}$ \\
\hline Dry matter (DM) & $92.05 \mathrm{~g} \mathrm{~kg}^{-1}$ \\
Crude protein (CP)* & $920.7 \mathrm{~g} \mathrm{~kg}^{-1}$ & $13.64 \mathrm{~g} \mathrm{~kg}^{-1}$ \\
Neutral detergent fibre (NDF) & $108.2 \mathrm{~g} \mathrm{~kg}^{-1}$ & $29.64 \mathrm{~g} \mathrm{~kg}^{-1}$ \\
Acid detergent fibre (ADF) & $34.48 \mathrm{~g} \mathrm{~kg}^{-1}$ & $16.41 \mathrm{~g} \mathrm{~kg}^{-1}$ \\
Non-fibrous carbohydrate (NFC) & $20.63 \mathrm{~g} \mathrm{~kg}^{-1}$ & $49.57 \mathrm{~g} \mathrm{~kg}^{-1}$ \\
Ether extract (EE) & $47.60 \mathrm{~g} \mathrm{~kg}^{-1}$ & $2.21 \mathrm{~g} \mathrm{~kg}^{-1}$ \\
Mineral matter (MM) & $2.09 \mathrm{~g} \mathrm{~kg}^{-1}$ & $5.06 \mathrm{~g} \mathrm{~kg}^{-1}$ \\
Starch $^{* *}$ & $4.88 \mathrm{~g} \mathrm{~kg}^{-1}$ & $39.36 \mathrm{~g} \mathrm{~kg}^{-1}$ \\
Monensin $^{* *}$ & $33.84 \mathrm{~g} \mathrm{~kg}^{-1}$ & $39.76 \mathrm{mg} \mathrm{kg}^{-1}$ \\
\hline
\end{tabular}

70R:30C: extruded ration with 70\% roughage and 30\% concentrate; 30R:70C: extruded ration with 30\% roughage and 70\% concentrate.

* Values obtained after analyses made in the animal nutrition laboratory of the Animal Science course at the Federal University of Uberlândia and in partnership with the Federal Institute of the Triangulo Mineiro - campus Uberaba.

** Data provided by the manufacturer. 
The extruded feed was supplied twice a day (08h00 and 16h00). The leftovers were measured daily, and whenever the values were equal to zero, the quantity supplied was increased until it reached a surplus equivalent to $10 \%$ of the offered feed. Every day the leftovers were weighed to calculate DMI, using the formula: DMI $=($ food offer $\times \%$ dry matter of the offer) - (food leftovers $\times \%$ dry matter of leftovers). Given that the food offered and the leftovers were relative to the stall, to calculate the DMI for each animal, the result of the stalls' DMI was divided by five (number of animals per stall). The DMI in relation to live weight was obtained through the relationship between the DMI and the average body weight of the animals during the entire evaluation period.

Blood samples were collected to evaluate the glycaemic curve and biochemical components on day 0 (first day of adaptation) 30, 60, 90 and 105 of the experiment. The blood was always collected before the first feeding (with the animal fasting).

For the glycaemic assessment, the blood was collected at $08 \mathrm{~h} 00$ (before the first meal), 11h00, $14 \mathrm{~h} 00,17 \mathrm{~h} 00$ and $20 \mathrm{~h} 00$. On the day of the glycaemic evaluation, the second meal was only offered after the $20 \mathrm{~h} 00$ collection. The samples were collected by venipuncture of the jugular with the aid of $5 \mathrm{~mL}$ Vacutainer ${ }^{\circledR}$ tubes containing fluoride and ethylenediaminetetraacetic acid (EDTA). The tubes were properly identified for each animal.

For the evaluation of the biochemical components, blood samples were taken by venipuncture of the jugular with the aid of Vacutainer ${ }^{\circledR}$ tubes without anticoagulant. The biochemical components for determining energy metabolism were: triglycerides, cholesterol, very low-density lipoprotein (VLDL calculated by dividing the triglyceride value by 5), high-density lipoprotein (HDL), low-density lipoprotein (LDL) calculated through the formula proposed by Friedewald, Levv and Fredrickson (1972): $\mathrm{LDL}=[($ total cholesterol) $-(\mathrm{HDL})-(\mathrm{VLDL})]$ and fructosamine. The measures to determine liver function were: gamma-glutamyl transferase (GGT), aspartate aminotransferase (AST) and alkaline phosphatase. The measures to determine protein metabolism were: total protein, urea, albumin, uric acid and creatinine. The following parameters were used for mineral determination: magnesium $(\mathrm{Mg})$, calcium $(\mathrm{Ca})$, phosphorus $(\mathrm{P})$ and the $\mathrm{Ca}: \mathrm{P}$ ratio. Finally, creatine kinase (CK-NAC) was measured to determine muscle function.

The collected blood samples were centrifuged at 3000 rotations per minute (rpm) for 10 minutes, and the sera were aliquoted and stored in microtubes at $-5^{\circ} \mathrm{C}$ until further laboratory analysis. All samples were processed in an automated biochemical analyser (Bioplus ${ }^{\circledR} 2000$ ), using a commercial kit from Lab Test ${ }^{\circledR}$.

The data were subjected to normality and residual tests by W and D statistics (Shapiro \& Wilk, 1965; Lilliefors, 1967) and homoscedasticity of treatment variances (Levene, 1960). A completely randomised design with two treatments and 15 replicates was used; the periods were evaluated as repeated measures over time. For the variables in which the sphericity condition was not accepted, mixed model analysis was employedin which all covariance structures (S) were evaluated-using the SAS software package (Statistical Analysis System Institute [SAS Institute], 2012) to model the dependency of the model errors. To select the covariance structure that best explained the residual correlation, the Akaike information criterion (AIC) was used, and the structure that resulted in the lowest AIC value after analysis was chosen for each variable (Silva, Duarte, \& Reis, 2015).

To evaluate DMI, the stalls were used as a replicate; therefore, each treatment had three stalls as a replication unit. The blood glucose data was evaluated in sub-subdivided plots, with the subplots representing the periods and the sub-subplots indicating the collection times. The treatment means were evaluated by the Tukey test, and the collection periods and times were assessed by 
linear regression analysis in which the criterion for choosing the model (linear or quadratic) was observed, the significance of the coefficients, the non-significance of the linearity deviations and the highest $\mathrm{R}^{2}$, with these first two criteria evaluated at $5 \%$ probability of making a type I error.

\section{Results and Discussion}

The DMI in relation to body weight was higher $(\mathrm{P}=0.0258)$ for the 70R:30C compared to the 30R:70C treatment. There was no difference in the intake in kilograms per animal between the treatments (Table 2). The average DMI was 1.13 $\mathrm{kg}$ animal $^{-1}$ day $^{-1}$, which is within the recommended value for sheep (1.0-1.3 $\mathrm{kg} \mathrm{day}^{-1}$ (National Research Council [NRC], 2007). The DMI value in relation to body weight (DMI\% BW) recommended by the NRC (2007) is $3.51 \%$. The animals subjected to the 30R:70C treatment presented a DMI\% BW 3.4\% above the recommended value, while the animals that received the 70R:30C treatment presented a DMI\% BW 3.9\% above the recommended value.

Table 2

Dry matter intake (DMI) per animal and body weight (DMI\%BW) depending on treatments and period

\begin{tabular}{ccc}
\hline Treatment & DMI/animal $\left(\mathrm{kg} \mathrm{day}^{-1}\right)$ & DMI\%BW (\%) \\
\hline 30R:70C & 1.08 & $3.63 \mathrm{~B}$ \\
70R:30C & 1.18 & $4.00 \mathrm{~A}$ \\
\hline P value & & 0,0258 \\
\hline Period (day) & 0,1214 & $\mathrm{DMI}^{-1} \mathrm{BW}^{2}(\%)$ \\
\hline 15 & $\mathrm{DMI}^{-} \mathrm{animal}^{1}\left(\mathrm{~kg} \mathrm{day}^{-1}\right)$ & 4.27 \\
30 & 0.94 & 4.37 \\
45 & 1.09 & 4.04 \\
60 & 1.21 & 3.78 \\
75 & 1.14 & 3.62 \\
90 & 1.19 & 3.40 \\
105 & 1.23 & 3.20 \\
\hline P value & 1.24 & 0,0001 \\
Mean & 0,0017 & 3.81 \\
CV & 1.13 & 5.88 \\
\hline
\end{tabular}

70R:30C: extruded ration with 70\% roughage and 30\% concentrate; 30R:70C: extruded ration with 30\% roughage and 70\% concentrate; $\mathrm{CV}$ : coefficient of variation; different letters in the column differ by the Tukey test at $5 \%$; ${ }^{1} \mathrm{Y}=0.872929+0.006769 \mathrm{x}$ $-0.000031 \mathrm{x}^{2}, \mathrm{R}^{2}=94.91 \% ;{ }^{2} \mathrm{Y}=4.613843-0.013276 \mathrm{x}, \mathrm{R}^{2}=95.86 \%$.

The lower intake observed $(\mathrm{P}=0.0258)$ for the 30R:70C animals can be explained by the metabolic regulation of intake. The diet has highly fermentable amounts of energy and protein in the rumen; consequently, the amount ingested for maintenance and production may be higher than the nutritional requirement. Therefore, physiological mechanisms act to depress appetite and reduce food consumption
(Oliveira, Caetano, Caetano, Martins, \& Oliveira, 2017).

During the evaluated period, there was a quadratic effect $(\mathrm{P}=0.0017)$ for the DMI per animal in kilograms per day, with a greater intake for half to the end of the experiment. For the DMI expressed in $\% \mathrm{BW}$, there was a negative linear effect $(\mathrm{P}=$ 
0.0001 ), with a lower $\mathrm{DMI} \% \mathrm{BW}$ at the end of the experimental period. The DMI\%BW is the weight gain of the animals, which at the end of the experiment was higher; hence, even when the amount ingested (in pounds) increased, the DMI\%BW was reduced. These animals, when young, have fewer nutritional requirements, and because they are lighter even if they eat less food a day, when this intake is relative to body weight, their DMI\%BW is higher. However, as these animals grow, their nutritional requirement also increases, with a greater daily intake required to meet their physiological demands. Together with the high consumption, the animals begin their fattening process and become heavier. Thus, when the relationship between this intake and their body weight was assessed, this measure was reduced (Zanine \& Macedo, 2006).
There was no difference between treatments $(\mathrm{P}>$ 0.0500 ) with regard to the concentration of energyrelated metabolites (Table 3). However, there were difference between the feeds for cholesterol, HDL, VLDL, fructosamine and the relationship between cholesterol and HDL. The cholesterol, HDL and LDL values were $38 \%, 54 \%$ and $58 \%$, respectively, below the reference values. The low ether extract content in the extruded feed (Table 1) may have influenced the reduction of the concentration of these metabolites in the blood. Villa, Pulgarín, Tabares, Angarita and Ceballos (2009) stated that plasma total cholesterol levels are adequate indicators of total plasma lipids and have a direct relationship with the animal's diet.

\section{Table 3}

Effect of different roughage to concentrate ratios in the extruded feed and the period on the blood concentration of energy metabolites

\begin{tabular}{ccccccccc}
\hline Treatment & CHOL & TRI & HDL & LDL & VLDL & CT/HDL & LDL/HDL & FRUCT \\
\hline 30R:70C & 31.73 & 16.65 & 23.13 & 12.05 & 3.31 & 1.41 & 0.54 & 205.06 \\
70R:30C & 32.26 & 15.40 & 21.46 & 12.61 & 3.08 & 1.56 & 0.64 & 209.25 \\
\hline P value & 0,8963 & 0,7458 & 0,3369 & 0,4278 & 0,9874 & 0,1574 & 0,2017 & 0,8963 \\
\hline Period (days) & CHOL $^{1}$ & TRI & HDL $^{2}$ & LDL & VLDL $^{3}$ & CT/HDL $^{4}$ & LDL/HDL & FRUCT $^{5}$ \\
\hline 0 & 29.16 & 13.13 & 16.85 & 13.33 & 2.62 & 1.68 & 0.82 & 256.43 \\
30 & 31.16 & 15.43 & 22.53 & 9.31 & 3.08 & 1.40 & 0.41 & 275.13 \\
60 & 36.80 & 15.63 & 21.50 & 15.10 & 3.12 & 1.78 & 0.74 & 156.87 \\
90 & 38.73 & 16.80 & 26.76 & 16.29 & 3.36 & 1.51 & 0.65 & 166.87 \\
105 & 23.60 & 19.32 & 23.89 & 7.30 & 3.86 & 1.03 & 0.32 & 178.83 \\
\hline P value & 0,0142 & 0,8521 & 0,0458 & 0,5259 & 0,0512 & 0,0014 & 0,6710 & 0,0029 \\
Mean & 32.00 & 16.02 & 22.28 & 12.33 & 3.20 & 1.49 & 0.59 & 207.91 \\
CV & 39.61 & 36.72 & 23.83 & 39.71 & 36.72 & 35.16 & 53.63 & 33.06 \\
RV & $52-76^{*}$ & $9-30^{*}$ & $49-53^{*}$ & $29.4-65.9 * *$ & $3-4^{*}$ & & & $170-174 *$ \\
\hline
\end{tabular}

70R:30C: extruded ration with 70\% roughage and 30\% concentrate; 30R:70C: extruded ration with 30\% roughage and $70 \%$ concentrate; RV: reference values; *reference values described by Kaneko, Harvey and Bruss (2008); ** Reference values described by Ghoreishi, Zamiri, Rowghani and Hejazi (2007) and Espinoza, Palacios, Ortega and Guillén (2008); CHOL: cholesterol (mg $\mathrm{dL}^{-1}$ ); TRI: triglycerides (mg dL $\left.{ }^{-1}\right)$; HDL: high-density lipoprotein ( $\left.\mathrm{mg} \mathrm{dL}^{-1}\right)$; LDL: low-density lipoprotein (mg dL $\left.{ }^{-1}\right)$; VLDL: very low-density lipoprotein ( $\left.\mathrm{mg} \mathrm{dL}^{-1}\right)$; CT/HDL: relationship between cholesterol and high-density lipoprotein; LDL/HDL: relationship between low-density lipoprotein and high-density lipoprotein; FRUCT: fructosamine $\left(\mu \mathrm{mg} \mathrm{dL}^{-1}\right)$; CV: coefficient of variation; ${ }^{1} \mathrm{Y}=$ $27.328566+0.357717 \mathrm{x}-0.003349 \mathrm{x}^{2}, \mathrm{R}^{2}=47.39 \% ;{ }^{2} \mathrm{Y}=18.251087+0.071204 \mathrm{x}, \mathrm{R}^{2}=70.83 \% ;{ }^{3} \mathrm{Y}=2.651463+0.009849 \mathrm{x}, \mathrm{R}^{2}=$ $88.06 \% ;{ }^{4} \mathrm{Y}=1.572572+0.006991 \mathrm{x}-0.000103 \mathrm{x}^{2}, \mathrm{R}^{2}=52.90 \% ;{ }^{5} \mathrm{Y}=264.635325-1.014425 \mathrm{x}, \mathrm{R}^{2}=63.24 \%$. 
There was an increase $(\mathrm{P}=0.0458)$ in the HDL concentration and a reduction in the LDL concentration at the end of the experiment, and thus a lower HDL/LDL ratio. This change is beneficial to the animal because HDL is responsible for the transport of cholesterol from extrahepatic tissues to the liver, where it will be metabolised. On the other hand, LDL is responsible for transporting cholesterol in the opposite direction: from the liver to the other tissues of the body, where it is accumulated and can cause venous and arterial blockage/impairment (Campbell \& Farrel, 2001; Souza, Uribe-Velásquez, Ramos, \& Oba, 2006). The relationship between cholesterol and HDL was also reduced at the end of the experimental period; these data indicate that the animal had a high capacity for transporting fatty acids to the liver, which were when metabolised to generate more energy. This outcome also explains the lower concentration of cholesterol in these animals.

Triglycerides and VLDL remained within the reference values (Table 3) throughout the experimental period, but VLDL exhibited a positive linear effect: it increased during the experimental period. VLDL is a lipoprotein that transports triglycerides in the bloodstream. Due to its increase, there was a greater capacity for transporting triglycerides at the end of the experiment, a change associated with a higher capacity for transporting cholesterol via HDL. This phenomenon indicates greater energy production in these animals.

Fructosamine showed a negative linear effect $(\mathrm{P}=$ $0.0029)$ during the analysed period; the concentration was lower at the end of the experiment. Fructosamine is a stable ketoamine that is formed when glucose reacts non-enzymatically with amino groups of proteins, mainly albumin and immunoglobulin. Its plasma or serum concentration is controlled by the balance between the synthesis and elimination of these protein and glucose compounds (Gouveia et al., 2015). Therefore, it is possible to associate this decrease in the fructosamine concentration with the decrease in the DMI\%BW (Table 2) and the glucose concentration at the end of the experiment (Table 4).

Table 4

Interaction between treatment and assessment time as well as confinement period on glucose concentration $\left(\mathrm{mg} \mathrm{dL}^{-1}\right)$

\begin{tabular}{|c|c|c|c|c|c|c|}
\hline Treatment & 08h00 & $11 \mathrm{~h} 00$ & $14 \mathrm{~h} 00$ & $17 \mathrm{~h} 00$ & $20 \mathrm{~h} 00$ & $P$ value \\
\hline 30R:70C ${ }^{1}$ & 87.00 & 77.40 & 97.49 & 93.70 & 89.60 & 0,0025 \\
\hline $70 \mathrm{R}: 30 \mathrm{C}^{2}$ & 88.18 & 81.60 & 98.36 & 92.62 & 98.37 & 0,0000 \\
\hline Mean & \multicolumn{6}{|c|}{90.42} \\
\hline $\mathrm{CV}$ & \multicolumn{6}{|c|}{16.07} \\
\hline $\mathrm{RV}^{*}$ & \multicolumn{6}{|c|}{$50-80$} \\
\hline Period (days) & \multicolumn{6}{|c|}{ Glucose $^{3}$} \\
\hline 0 & \multicolumn{6}{|c|}{73.82} \\
\hline 30 & \multicolumn{6}{|c|}{86.65} \\
\hline 60 & \multicolumn{6}{|c|}{114.25} \\
\hline 90 & \multicolumn{6}{|c|}{84.96} \\
\hline 105 & \multicolumn{6}{|c|}{92.26} \\
\hline P value & \multicolumn{6}{|c|}{0,0047} \\
\hline
\end{tabular}

70R:30C: extruded ration with 70\% roughage and 30\% concentrate; 30R:70C: extruded ration with 30\% roughage and 70\% concentrate; RV: reference values; *reference values described by Kaneko et al. (2008); CV: coefficient of variation; ${ }^{1} \mathrm{Y}=60.783274$ $+3.583565 \mathrm{x}-0.102391 \mathrm{x}^{2}, \mathrm{R}^{2}=24.95 \% ;{ }^{2} \mathrm{Y}=77.176000+1.046667 \mathrm{x}, \mathrm{R}^{2}=48.33 \% ;{ }^{3} \mathrm{Y}=73.648107+0.764514 \mathrm{x}-0.005394 \mathrm{x}^{2}$, $\mathrm{R}^{2}=50.92 \%$. 
There was an interaction between treatment and assessment time for the glucose concentration (Table 4). There was a quadratic effect $(\mathrm{P}=0.0025)$ for the 30R:70C treatment; the treatment with the highest non-fibrous carbohydrate content (Table 1) provided more soluble carbohydrates with a high fermentation capacity and generated more energy for the animal. In ruminant animals, plasma glucose is generated from non-carbohydrate precursors, such as the volatile fatty acid (VFA) propionate. After absorption of propionate by the ruminal epithelium, it travels through the bloodstream to the liver, where it is converted into glucose through gluconeogenesis to be used as an energy source by the animal (González, 2000a). A high dietary soluble carbohydrate supply increases the production of propionic acid, which is the only VFA precursor for glucose in ruminants. Thus, a higher supply of soluble carbohydrates increased the plasma glucose concentration.

Nevertheless, the 70R:30C treatment promoted a positive linear glucose response $(\mathrm{P}=0.0000)$, with a lower value at $11 \mathrm{~h} 00$. The lower glucose concentration at this time is due to the fact that these animals had consumed the food provided in the morning and were in the process of degrading and fermenting the extruded feed in their rumen, processes that demands high energy expenditure and reduce the glucose concentration during this period.

There was a quadratic effect $(\mathrm{P}=0.0047)$ for the glucose concentration when the period of ration use was evaluated, with a drop in values at the end of the experimental period. This response profile can be associated with the DMI\%BW of these animals (Table 2), with lower glucose and DMI\%BW at the same times, as well as the fructosamine concentration that was reduced during the experimental period (a metabolite indicative of the presence of glucose in the body).

It was possible to associate the response pattern of energy metabolites with the composition of the diet and the DMI (Tables 1 and 2). The ingredients with the highest fermentative capacity due to the extrusion process associated with the largest DMI over the experimental period provided greater energy production for the animal. Specifically, it increased the transport capacity of cholesterol and triglycerides and concentrations of fructosamine and blood glucose above the recommended for the animal category.

Of the protein metabolites, only urea exhibited treatment effects $(\mathrm{P}=0.0452)$, with a $31 \%$ higher concentration in the 30R:70C compared to the 70R:30C treatment (Table 5). This effect was probably because the treatment with the highest concentrate content had a higher crude protein content in the feed (Table 1), a factor associated with greater nutrient solubility caused by the extrusion process. Indeed, according to Contreras and Phil (2000), the higher the protein intake in the ration, the higher the blood concentration of this metabolite. In addition, the nitrogen present in the concentrate is more soluble, a factor that allows for greater ammonia production in the rumen. If this ammonia is not used for the production of microbial protein, it escapes the rumen to the liver, where urea production occurs. This activity increases the concentration of urea in the blood.

Regarding the period of feed use, there was no difference for albumin. Urea, creatinine and total proteins showed a quadratic effect, findings that may be associated with the DMI\%BW of these animals (Table 2) because the highest concentration of these metabolites coincided with the period of greatest intake.

Uric acid also showed a quadratic response (P $=0.0489$ ), but with higher values at the beginning and end of the experiment. When there was a higher concentration of uric acid in the blood, there was a lower concentration of urea (Table 5). Uric acid is directly related to the synthesis of microbial protein by ruminal microorganisms, so when there is a higher concentration of this metabolite, there 
is greater microbial synthesis and, consequently, more use of ruminal ammonia. This phenomenon reduces its escape and subsequent urea production in the liver. Hence, there was a lower urea plasma concentration.

Table 5

Effect of different roughage to concentrate ratios in extruded feed on blood concentration of protein metabolites

\begin{tabular}{lccccc}
\hline Treatment & TP & ALB & CREAT & Urea & UA \\
\hline 30R:70C & 4.39 & 2.93 & 0.86 & $53.88 \mathrm{~A}$ & 0.152 \\
70R:30C & 4.53 & 3.03 & 0.88 & $41.22 \mathrm{~B}$ & 0.176 \\
\hline P value & 0,8871 & 0,6971 & 0,7541 & 0,0452 & 0,3210 \\
\hline Period (days) & $\mathrm{TP}^{1}$ & ALB & CREAT $^{2}$ & Urea $^{3}$ & UA $^{4}$ \\
\hline 0 & 3.80 & 3.02 & 0.93 & 38.73 & 0.153 \\
30 & 4.29 & 2.59 & 0.92 & 46.90 & 0.113 \\
60 & 5.10 & 2.77 & 0.97 & 57.86 & 0.040 \\
90 & 4.87 & 3.95 & 0.74 & 56.96 & 0.186 \\
105 & 4.21 & 2.54 & 0.77 & 34.82 & 0.332 \\
\hline P value & 0,0012 & 0,3321 & 0,0001 & 0,0174 & 0,0489 \\
Mean & 4.46 & 2.98 & 0.87 & 47.22 & 0.164 \\
CV & 11.18 & 16.77 & 19.05 & 31.58 & 47.48 \\
RV* & $6-7.9$ & $2.4-3$ & $1.2-1.9$ & $17.1-42.8$ & $0.1-2$ \\
\hline
\end{tabular}

70R:30C: extruded ration with 70\% roughage and 30\% concentrate; 30R:70C: extruded ration with 30\% roughage and 70\% concentrate; RV: reference values; *reference values described by Kaneko et al. (2008); TP: total protein (g d L $\left.{ }^{-1}\right)$; ALB: albumin ( $\left.\mathrm{g} \mathrm{d} \mathrm{L}^{-1}\right)$; CREAT: creatinine ( $\left.\mathrm{mg} \mathrm{d} \mathrm{L}^{-1}\right)$; AU: uric acid $\left(\mathrm{mg} \mathrm{d} \mathrm{L}^{-1}\right)$; $\mathrm{CV}$ : coefficient of variation; different letters in the column differ by the Tukey test at $5 \% ;{ }^{1} \mathrm{Y}=3.685671+0.040036 \mathrm{x}-0.000319 \mathrm{x}^{2}, \mathrm{R}^{2}=83.00 \% ;{ }^{2} \mathrm{Y}=0.930049+0.001753 \mathrm{x}-0.000033 \mathrm{x}^{2}, \mathrm{R}^{2}=$ $73.82 \% ;{ }^{3} \mathrm{Y}=36.099060+0.757685 \mathrm{x}-0.006821 \mathrm{x}^{2}, \mathrm{R}^{2}=68.72 \% ;{ }^{4} \mathrm{Y}=0.171571-0.005468 \mathrm{x}+0.000065 \mathrm{x}^{2}, \mathrm{R}^{2}=90.67 \%$.

Plasma creatinine is almost entirely derived from the catabolism of creatine present in muscle tissue. Its plasma concentration is proportional to muscle mass and activity (González \& Silva, 2017). The creatinine concentration was below the recommended value and decreased $(\mathrm{P}=0.0001)$ at the end of the experiment. This outcome can be explained by the low muscle activity of these animals. Notably, the sheep were confined to stalls, and at the end of the experiment they were close to puberty, a period of reduced muscle growth. Indeed, muscle growth in sheep is not isometric; bone development is more intense during the initial phase of life, muscle growth is more prominent in the intermediate phase until puberty and adipose tissue production dominates in older age (Santos, Pérez, Siqueira, Muniz, \& Bonagúrio, 2001).
There was a higher $(\mathrm{P}=0.0098)$ blood concentration of phosphorus for 70R:30C compared to 30r:70c animals (Table 6), but the values of both treatments are above the reference value. Phosphorus exists in organic combinations within the cell; however, the main interest in the metabolic profile is in the inorganic phosphorus found in plasma. The inorganic phosphorous concentration can be influenced by the amount that is recycled via saliva and absorbed in the rumen and intestine (González, 2000b). The same author also stated that the concentration of phosphorus in the blood decreases as the animal ages, a phenomenon that explains the high concentrations found in this work, since they were young animals. 
Table 6

Effect of different roughage to concentrate ratios in extruded feed on blood concentration of mineral metabolites and liver enzymes

\begin{tabular}{ccccc}
\hline Treatment & $\begin{array}{c}\text { AST } \\
\left(\mathrm{U} \mathrm{L}^{-1}\right)\end{array}$ & $\begin{array}{c}\text { AP } \\
\left(\mathrm{U} \mathrm{L} \mathrm{L}^{-1}\right)\end{array}$ & $\begin{array}{c}\text { Phosphorus } \\
\left(\mathrm{mg} \mathrm{dL}^{-1}\right)\end{array}$ & $\begin{array}{c}\text { Calcium } \\
\left(\mathrm{mg} \mathrm{dL}^{-1}\right)\end{array}$ \\
\hline 30R:70C & 146.19 & 400.16 & $9.50 \mathrm{~B}$ & 8.17 \\
70R:30C & 139.14 & 456.82 & $10.37 \mathrm{~A}$ & 8.24 \\
P value & 0,5521 & 0,7493 & 0,0098 & 0,8896 \\
Period (days) & $\mathrm{AST}^{1}$ & $\mathrm{AP}^{2}$ & Phosphorus $^{3}$ & Calcium $^{4}$ \\
0 & 116.30 & 374.50 & 8.86 & 7.95 \\
30 & 118.33 & 445.40 & 10.02 & 8.32 \\
60 & 169.03 & 439.56 & 11.76 & 9.07 \\
90 & 161.03 & 438.60 & 10.62 & 8.43 \\
105 & 148.82 & 447.57 & 8.35 & 7.20 \\
\hline P value & 0,0031 & 0,0501 & 0,0078 & 0,0005 \\
Mean & 142.62 & 428.87 & 9.94 & 8.21 \\
CV & 29.76 & 12.05 & 19.66 & 21.09 \\
RV* & $60-280$ & $68-387$ & $5-7.3$ & $11.5-12.8$ \\
\hline
\end{tabular}

70R:30C: extruded ration with 70\% roughage and 30\% concentrate; 30R:70C: extruded ration with $30 \%$ roughage and $70 \%$ concentrate; RV: Reference values; *reference values described by Kaneko et al. (2008); AST: aspartate aminotransferase; AP: alkaline phosphatase; CV: coefficient of variation; different letters in the column differ by the Tukey test at $5 \% ;{ }^{1} \mathrm{Y}=118.448171$ $+0.425546 \mathrm{x}, \mathrm{R}^{2}=56.68 \% ;{ }^{2} \mathrm{Y}=381.592160+1.923633 \mathrm{x}-0.013145 \mathrm{x}^{2}, \mathrm{R}^{2}=82.92 \% ;{ }^{3} \mathrm{Y}=8.539628+0.015894 \mathrm{x}-0.000984 \mathrm{x}^{2}$, $\mathrm{R}^{2}=81.02 \% ;{ }^{4} \mathrm{Y}=7.784817+0.046198 \mathrm{x}-0.000470 \mathrm{x}^{2}, \mathrm{R}^{2}=78.79 \%$.

There was a quadratic effect $(\mathrm{P}=0.0005)$ for the calcium concentration during the experimental period, with a reduction at the end of the experiment (Table 6). The average calcium concentration was $28 \%$ below the recommendation for sheep. Calcium is a macromineral that is involved in several functions in animals, such as neuromuscular excitability, membrane permeability, muscle contraction, enzymatic activity, hormone release and blood clotting, in addition to being an essential component for skeletal structures (González, 2000b; Gênova $\&$ Paulino, 2011). These authors also reported that there is a continuous exchange of calcium between the blood plasma and bone. The calcium absorbed from the diet would increase the blood concentration and is deposited quickly in bone tissue. On the other hand, the calcium in bones is mobilised when the blood calcium concentration decreases. Therefore, as the animals in this experiment were young and were in continuous growth, the calcium present in the plasma may have been mobilised to bone structures, thus reducing their blood concentration.

There was a positive linear effect $(\mathrm{P}=0.0031)$ for AST when the period of feed use was evaluated. However, these numbers are within the reference value, indicating that there was no hepatic alteration in these animals. There was a quadratic effect on the concentration of alkaline phosphatase, phosphorus and calcium during the period of use: the concentration of these metabolites was higher at the same time that there was a higher DMI $\% \mathrm{BW}$ per animal (Table 2). This finding may explain the elevation of such metabolites.

According to Kaneko et al. (2008), alkaline phosphatase is synthesised in various tissues, with the highest concentrations in the intestine, kidneys, bones and liver. An increase in alkaline phosphatase in the blood plasma is a consequence of damage to the liver. At the end of the experimental period, the 
concentration of alkaline phosphatase was $15.6 \%$ above the reference value (Table 6). Notably, the average GGT concentration was $82.7 \%$ above the reference value; this enzyme also indicates liver activity. Given that the animals did not show any liver disorders (Kaneko et al., 2008), this increase in the enzyme concentrations indicates that the liver was in constant and intense activity because the DMI was elevated (Table 2).

There was an interaction between treatment and period for the GGT, CK NAC and magnesium blood concentrations (Table 7). The GGT concentration showed a positive linear response for the 30R:70C treatment and a quadratic response for the $70 \mathrm{R}: 30 \mathrm{C}$ treatment throughout the experimental period. However, there was a higher concentration of GGT for the 30R:70C treatment on day 105 of the experiment. GGT is present in all tissues except muscle. It has great activity in the kidneys and liver, but only GGT of hepatic origin is normally found in the plasma; renal GGT is usually excreted in the urine. Elevated serum GGT are seen mainly in animals with liver disorders (Kaneko et al., 2008). However, there the increase in the DMI (Table 2), accompanied by the intense liver activity, supports the lack of liver disorders in these animals.

Table 7

Interaction between treatment and period on the concentration of the metabolites gamma-glutamyl transferase (GGT), creatine kinase (CK NAC) and magnesium

\begin{tabular}{|c|c|c|c|c|c|c|}
\hline \multirow{2}{*}{ Period (days) } & \multicolumn{2}{|c|}{ GGT $\left(\mathrm{U} \mathrm{L}^{-1}\right)$} & \multicolumn{2}{|c|}{ CK NAC $\left(\mathrm{U} \mathrm{L}^{-1}\right)$} & \multicolumn{2}{|c|}{ Magnesium $\left(\mathrm{mg} \mathrm{dL}^{-1}\right)$} \\
\hline & 30R:70C ${ }^{1}$ & $70 \mathrm{R}: 30 \mathrm{C}^{2}$ & 30R:70C & $70 \mathrm{R}: 30 \mathrm{C}^{3}$ & 30R:70C 4 & $70 \mathrm{R}: 30 \mathrm{C}^{5}$ \\
\hline 0 & 79.26 & 85.06 & 119.66 & 204.66 & 2.87 & 3.20 \\
\hline 30 & 89.13 & 88.13 & 178.13 & 116.73 & 2.78 & 3.00 \\
\hline 60 & 112.73 & 109.80 & 176.60 & 175.97 & 2.20 & 2.86 \\
\hline 90 & 100.00 & 86.62 & 142.07 & 253.81 & 2.03 & 2.12 \\
\hline 105 & $114.64 \mathrm{~A}$ & $86.71 \mathrm{~B}$ & 132.14 & 135.28 & $1.67 \mathrm{~B}$ & $2.36 \mathrm{~A}$ \\
\hline$P$ value & 0,0014 & 0,0089 & 0,2514 & 0,0063 & 0,0001 & 0,0001 \\
\hline Mean & \multicolumn{2}{|c|}{95.04} & \multicolumn{2}{|c|}{164.66} & \multicolumn{2}{|c|}{2.51} \\
\hline $\mathrm{CV}$ & \multicolumn{2}{|c|}{22.15} & \multicolumn{2}{|c|}{56.31} & \multicolumn{2}{|c|}{20.77} \\
\hline $\mathrm{RV}^{*}$ & \multicolumn{2}{|c|}{$20-52$} & & & \multicolumn{2}{|c|}{$2.2-2.8$} \\
\hline
\end{tabular}

70R:30C: extruded ration with 70\% roughage and 30\% concentrate; 30R:70C: extruded ration with $30 \%$ roughage and $70 \%$ concentrate; RV: reference values; *reference values described by Kaneko et al.(2008); CV: coefficient of variation; Different letters in the same line differ by the Tukey test at $5 \% ;{ }^{1} \mathrm{Y}=82.037805+0.300306 \mathrm{x}, \mathrm{R}^{2}=72.27 \% ;{ }^{2} \mathrm{Y}=82.501032+0.644270$ $-0.005917 \mathrm{x}^{2}, \mathrm{R}^{2}=50.70 \% ;{ }^{3} \mathrm{Y}=$ Equation did not fit the model; ${ }^{4} \mathrm{Y}=2.963783-0.011109 \mathrm{x}, \mathrm{R}^{2}=91.98 \% ;{ }^{5} \mathrm{Y}=3.268552-$ $0.010062 \mathrm{x}, \mathrm{R}^{2}=80.92 \%$.

The trend in the GGT concentration data during the analysed period is also a consequence of the diet composition (Table 1). The positive linear increase in GGT observed in the 30R:70C extruded feed is the result of consuming a diet with highly fermentable non-structural carbohydrates from the concentrate, which after fermentation and ruminal absorption are metabolised in the liver, a phenomenon that increases liver activity. For the 70R:30C ration, there was a quadratic effect for GGT, with higher values in the middle of the experiment. In other words, due to the increase structural carbohydrates in the diet, the time spent for fermentation and ruminal absorption was longer and, consequently, the liver activity was reduced. 
There was an interaction between the 70R:30C treatment with a negative linear effect on the evaluation period (Table 7) for the blood CK NAC concentration. According to González (2000a), CK NAC values up to $200 \mathrm{U} \mathrm{L}^{-1}$ are considered normal. Therefore, the average CK NAC values in this experiment remained within the recommended value. CK NAC is a specific skeletal muscle enzyme of great importance in the evaluation of muscle function. $\mathrm{CK}$ is the most sensitive enzyme with regard to muscle injury because it is a cytoplasmic enzyme that is subject to rapid release into the circulation as a result of a minor injury (Soares, 2004). CK NAC values may be altered in various clinical conditions associated with acute muscle injury or intense muscle strain. The AST enzyme increases concomitantly with CK NAC when muscle damage occurs, but as both were within normal limits (Tables 6 and 7), the animals did not apparently suffer any muscle damage or injury. Hence, their growth was not impaired; they were young animals in the phase with the greatest muscle development.

There was an interaction between treatment and period for the magnesium blood concentration (Table 7), with a negative linear effect during the evaluation period and a higher concentration of magnesium in 70R:30C animals at the end of the experimental period. However, throughout the experiment, the averages were within the reference values. These data indicated that the supplementation of this mineral in the extruded feed was sufficient.

Overall, there was intense liver activity in the animals, as demonstrated by the concentrations of the enzymes AST, GGT and alkaline phosphatase. These enzyme concentrations were not indicative of liver disorders; rather, they suggested intense activity in the liver. Indeed, the largest DMI associated within the characteristic of extrusion generated a greater amount of nutrients to be metabolised in the liver after ruminal fermentation.

\section{Conclusion}

The roughage to concentrate ratio of extruded feed influences the dry matter intake without triggering metabolic disorders in animals.

\section{References}

Campbell, M. K., \& Farrel, S. (2001). Bioquímica. São Paulo, SP: Cengage Learning.

Conrad, H. R., Weiss, W. P., Odwongo, W. O., \& Shockey, W. L. (1984). Estimating net energy lactation from components of cell solubles and cell walls. Journal of Dairy Science, 67(2), 427-436. doi: 10.3168/jds. S0022-0302(84)81320-X

Contreras, P. A., \& Phil, M. (2000). Indicadores do metabolismo proteico utilizados nos perfis metabólicos de rebanhos. In: F. H. D. González, J. Barcellos, H. O. Patiño, \& L. A. Ribeiro (Eds.), Perfil metabólico em ruminantes: seu uso em nutrição e doenças nutricionais (pp. 23-30). Porto Alegre, RS: UFRGS.

Espinoza, J. L., Palacios, A., Ortega, R., \& Guillén, A. (2008). Efecto de lasuplementación de grasas sobre lasconcentraciones séricas de progesterona, insulina, somatotropina y algunos metabolitos de loslípidos em ovejas Pelibuey. Archivos de Medicina Veterinaria, 40(2), 135-140. doi: 10.4067/S0301732 X2008000200004

Friedewald, W. T., Levv, R. I., \& Fredrickson, D. S. (1972). Estimation of the concentration of lowdensity lipoprotein in plasma, without use of the preparative ultracentrifuge. Clinical Chemistry, 18(6), 499-502. Retrieved from http://clinchem. aaccjnls.org/content/clinchem/18/6/499.full.pdf

Gênova, L. G., \& Paulino, V. T. (2011). Aspectos relacionados a cálcio e fósforo em equídeos e ruminantes. Publicações em Medicina Veterinária e Zootecnia, 5(24), art. 1155. Retrieved from http://www.pubvet.com.br/artigo/1772/aspectosrelacionados-a-caacutelcio-e-foacutesforo-emequiacutedeos-e-ruminantes

Gesualdi, A., Jr., Paulino, M. F., Valadares, S. C., Fo ., Silva, J. F. C., Veloso, C. M., \& Cecon, P. R. (2000). Níveis de concentrado na dieta de novilhos F1 Limousin $\mathrm{x}$ Nelore: Consumo, conversão alimentar e ganho de peso. Revista Brasileira de Zootecnia, 29(5), 14581466. doi: 10.1590/S1516-35982000000500026

Ghoreishi, S. M., Zamiri, M. J., Rowghani, E., \& Hejazi, H. (2007). Effect of a calcium soap of fatty 
acids on reproductive characteristics and lactation performance of fat-tailed sheep. Pakistan Journal of Biological Sciences, 10(14), 2389-2395. doi: 10.3923/pjbs.2007.2389.2395

González, F. H. D. (2000a). Uso do perfil metabólico no diagnóstico de doenças metabólico-nutricionais em ruminantes. In F. H. D. González, J. Barcellos, H. O. Patiño., \& L. A. Ribeiro (Eds.), Perfil metabólico em ruminantes: seu uso em nutrição e doenças nutricionais (pp. 80-106). Porto Alegre, RS: UFRGS.

González, F. H. D. (2000b). Indicadores sanguíneos do metabolismo mineral em ruminantes. In H. D. González, J. Barcellos, H. O. Patiño., \& L. A. Ribeiro (Eds.), Perfil metabólico em ruminantes: seu uso em nutrição e doenças nutricionais (pp. 31-51). Porto Alegre, RS: UFRGS.

González, F. H. D., \& Silva, S.C. (2017). Perfil bioquímico sanguíneo. In F. H. D., González, \& S. C Silva (Eds.), Introdução à bioquímica clínica veterinária (pp. 467-516). Porto Alegre, RS: UFRGS.

Gouveia, L. N. F., Maciel, M. V., Soares, P. C., Silva, I. F., Neto, Gonçalves, D. N. A., Batista, A. M. V., \& Carvalho, F. F. R. (2015). Perfil metabólico de ovinos em crescimento alimentados com dietas constituídas de feno ou silagem de maniçoba e palma forrageira. Pesquisa Veterinária Brasileira, 35(supl. 1), 5-9. doi: 10.1590/S0100-736X2015001300002

Kaneko, J. J., Harvey, J. W., \& Bruss, M. L. (2008). Clinical biochemistry of domestic animals. San Diego, CA: Academic Press.

Levene, H. (1960). Robust Tests for the equality of variance. In: L. J. Gleser, M. D. Perlman, S. J. Press, \& A. R. Sampson (Eds.), Contributions to Probability and Statistics (pp. 278-292). Palo Alto, California: Stanford University Press.

Lilliefors, H. W. (1967). On the Kolmogorov-Smirnov test for normality with mean and variance unknown. Journal of the American Statistical Association, 62(3), 399-402. doi: 10.2307/2283970

Mertens, D. R. (1987). Predicting intake and digestibility using mathematical models of ruminal function. Journal of Dairy Science, 64(5), 1548-1558. doi: $10.2527 /$ jas $1987.6451548 \mathrm{x}$

Mertens, D. R. (1994). Regulation of forage intake. Proceedings of National Conference on Forage Quality. Evaluation and Utilization, Linconl, USA.

Nacional Research Council (2007) Nutrient requirements of small ruminants: sheep, goats, cervids, and new world camelids. Washington, DC: National Academy Press.
Oliveira, B. C., Caetano, G. A. O., Caetano, M. B., Jr., Martins, T. R., \& Oliveira, C. B. (2017). Mecanismos reguladores de consumo em bovinos de corte. Nutritime Revista Eletrônica, 14(4), 1-10. Retrieved from http://www.nutritime.com.br/arquivos internos/artigos/Artigo_433.pdf

Pegoraro, M., Silva, L. D. F., Fernandes, F., Jr., Massaro, F. L., Jr., Fortaleza, A. P. S., Grandis, F. A.,... Castro, F. A. B. (2017). Nutritional assessment and in vitro degradation kinetics of protein concentrates utilized in ruminant feed. Revista Brasileira de Ciência Veterinária, 24(1), 31-38. doi: 10.4322/rbcv.2017.007

Santos, C. L., Pérez, J. R. O., Siqueira, E. R., Muniz, J. Á., \& Bonagúrio, S. (2001). Crescimento alométrico dos tecidos ósseo, muscular e adiposo na carcaça de cordeiros Santa Inês e Bergamácia. Revista Brasileira de Zootecnia, 30(2), 493-498. doi: 10.1590/S151635982001000200028

Statistical Analysis System Institute (2012). SAS user's guide: statistics. version 9.4. Cary: SAS Institute.

Shapiro, S. S., \& Wilk, M. B. (1965). An analysis of variance teste for normality. Biometrika, 52(4), 591611. doi: $10.2307 / 2333709$

Silva, E. N., Duarte, J. B., \& Reis, A. J. (2015). Seleção da matriz de variância-covariância residual na análise de ensaios varietais com medidas repetidas em cana-de-açúcar. Ciência Rural, 45(4), 993-999. doi: $10.1590 / 0103-8478 \mathrm{cr} 20141531$

Soares, E. C. (2004). Indicadores hematológicos e bioquímicos na avaliação da performance de equinos atletas. Porto Alegre, RS: UFRGS.

Souza, M. I. L., Uribe-Velásquez, L. F., Ramos, A. A., \& Oba, E. (2006). Níveis plasmáticos de colesterol total, lipoproteínas de alta densidade (HDL) e cortisol, e sua biorritmicidade, em carneiros IdealPolwarth. Ciência Animal Brasileira, 7(4), 433-438. Retrieved from https://www.revistas.ufg.br/ vet/ article/view/873/1012

Van Soest, P. J. (1994). Nutritional ecology of the ruminant. Ithaca, NY: Cornell University Press.

Villa, N. A., Pulgarín, E. F., Tabares, P. A., Angarita, E., \& Ceballos, A. (2009). Medidas corporales y concentración sérica y folicular de lípidos y glucosaen vacas Brahmanfértiles y subfértiles. Pesquisa Agropecuária Brasileira, 44(9), 11981204. doi: 10.1590/S0100-204X2009000900019

Zanine, A., \& Macedo, G. L., Jr. (2006). Importância do consumo da fibra para nutrição de ruminantes. Revista Eletrônica de Veterinária, 7(2), 1-11. Retrieved from http://www.veterinaria.org/revistas/ redvet/n040406/040613.pdf 
